\title{
Erratum to: Geotechnical Investigations and Proposal for Stabilization and Recovery \\ Slope on Highway BR-010 Stretch \\ in Aparecida do Rio Negro to Goiatins, \\ Tocantins, Brazil
}

\author{
Rideci Farias, Haroldo Paranhos, Jovino Rachid Araújo, \\ Leonardo Ramalho Sales, and Roberto Pimentel
}

\section{Erratum to: \\ Chapter "Geotechnical Investigations and Proposal for Stabilization and Recovery Slope on Highway BR-010 Stretch in Aparecida do Rio Negro to Goiatins, Tocantins, Brazil" in: W. Frikha et al. (eds.), Soil Testing, Soil Stability and Ground Improvement, https://doi.org/10.1007/978-3-319-61902-6_32}

In the original version of the book, the incorrectly captured author name "Leonardo Ramanho Sales" has to be corrected as "Leonardo Ramalho Sales" in the chapter "Geotechnical Investigations and Proposal for Stabilization and Recovery Slope on Highway BR-010 Stretch in Aparecida do Rio Negro to Goiatins, Tocantins, Brazil”. The erratum chapter and the book have been updated with the change.

The updated online version of this chapter can be found at https://doi.org/10.1007/978-3-319-61902-6_32 